\title{
Origin of and resulting floristic composition from seedbanks in agroforestry systems of Tomé-Açu, Eastern Amazon
}

\author{
F LACERDA*, I MIRANDA*, T T S LIMA*, N A MAFRA*, F M LEÃO $\dagger$, \\ I DO VALE*, C J C BISPO $\$$ \& O R KATO§ \\ *Universidade Federal Rural da Amazônia (UFRA), Belém, Brazil, †Universidade Federal do Pará (UFPA), Altamira, Brazil, \\ \$Universidade Estadual do Pará (UEPA), Belém, Brazil, and §Embrapa Amazônia Oriental, Belém, Brazil
}

Received 5 August 2015

Revised version accepted 5 January 2016

Subject Editor: David Clements, Trinity Western University, Canada

\section{Summary}

The objective of this study was to verify the origin of and resulting floristic composition from seedbanks in different agroforestry systems in Tomé-Açu, Brazil. The seedbanks were sampled in three smallholder farmers (Demonstration Units $=$ DU), each with three agroforestry treatments and secondary forest as control. Seedling emergence in a glasshouse was used to quantify and identify the seeds collected in 2008. The floristic composition of the above-ground community was characterised with annual floristic surveys from 2008 to 2011. The total densities and diversity of the seedbanks were not different among the treatments within a given DU, but differences occurred among DU. The most abundant woody species had higher seed densities in the secondary forests than in DU. Conversely, among the herbaceous species, two groups were differentiated: species with similar densities between the DU and the secondary forest and species with higher density in the DU. In the DU, the similarity between the floristic composition of the seedbank and the flora surveyed in 2008 was high, but decreased in subsequent years. The species present in the seedbank of agroforestry systems are highly influenced by the secondary forest, but provide little information about the floristic composition that will arise in the future.

Keywords: agroecology, biodiversity, fallow, oil palm, secondary forestry.

Lacerda F, Miranda I, Lima TTS, Mafra NA, Leão FM, Do Vale I, Bispo CJC \& Kato OR (2016). Origin of and resulting floristic composition from seedbanks in agroforestry systems of Tomé-Açu, Eastern Amazon. Weed Research 56, 219-228.

\section{Introduction}

Family agriculture in the Amazon is based on cutting and burning the forest to establish crops and pastures and on the use of fallow for the recovery of the soil properties. This system was described by Kass and Somarriba (1999). In general, there is no use of chemical products, such as herbicides and fertilisers, because of the high cost they represent for small producers. Thus, reducing weed populations involves frequent hand-weeding, especially in the first years of production, which can also have a high cost.

However, several plants that are undesirable in plantations (i.e. in oil palm) are beneficial to the system, because they promote forest regeneration during the next fallow period. During this period, a natural 
process of forest regeneration occurs, giving rise to a secondary forest that is popularly known in Brazil as capoeira. The fallow period is considered a good suppressor of weeds in family agriculture or pasture (Akobundu et al., 1999). Therefore, differentiating weeds from the beneficial plants that promote regeneration is essential to maintain the sustainability of this system.

Weeds possess dormant seeds that may persist in the soil for several years (Davis et al., 2005) and, thus, can re-infest agricultural areas for several years (Davis et al., 2008). In arable fields, the soil disturbance and the high nutrient availability may stimulate germination. However, in environments with decomposing residues in the soil (for example, mulch), germination may be reduced (Benech-Arnold et al., 2000).

Most weed seeds originate from plants that occur in the same location $(95 \%$, according to Hume \& Archibold, 1986); however, the density and the floristic composition of both the seedbank and the above-ground community respond to environmental variables (Albrecht \& Auerswald, 2003) and to agricultural practices, such as soil preparation (Tuesca et al., 2001), crop rotation (Smith et al., 2009) and weed management (Baumgartner et al., 2007).

Some studies show a weak relationship between the floristic composition of the seedbank and the floristic composition of the above-ground community (Davis et al., 2005; Steenwerth et al., 2010). This weak relationship can result from temporal and spatial heterogeneity associated with the management of weeds in the field (Forcella et al., 1996). The spatial and temporal heterogeneity can relate to environmental conditions (Albrecht \& Auerswald, 2003), quantity of seeds available in the soil (Luschei, 2003) and also dormant stage of seeds.

Understanding the relationship between the soil seedbank and the established flora can assist in longterm weed management. In family-based agriculture systems in the Amazon, such dynamics have not yet been elucidated, although Mitja et al. (2008), Miranda et al. (2009) and Mitja and Miranda (2010) have shown that, in recently colonised areas, the current plants are strongly influenced both by the forest species that occurred in the system prior to the removal of the forest and by the composition of adjacent forests.

The main objective of this study was to verify the origin of and resulting floristic composition from soil seedbanks in different agroforestry systems in ToméAçu, Eastern Amazon, Brazil. The results would contribute to select best management practices that promote regeneration in order to maintain the sustainability of the system. The hypotheses tested were that: (i) the species present in the seedbank of agroforestry systems originate from the secondary forest (thus preserving the species that will promote forest regeneration during the subsequent fallow periods), (ii) the diversity and density of the seedbank are influenced by soil preparation and arrangement of crops species and (iii) there is a high relationship between the floristic composition of the seedbank and above-ground communities established in subsequent years.

\section{Materials and methods}

\section{Study area}

The field study was carried out in the municipality of Tomé-Açu, located in north-eastern Pará State. The Tomé-Açu climate is Köppen-type 'Ami', with an average annual temperature of $26.5^{\circ} \mathrm{C}$ and $2663 \mathrm{~mm}$ of rain annually, most of which falls between December and May. Soils in the area are a mix of oxisols and ultisols (Moran et al., 2000) and acidic clay soils with few major nutrients.

\section{Experimental design}

Three demonstration units (DU) were established on the farms of three small family producers in Tomé-Açu, state of Pará, Eastern Amazon, Brazil (DU1 - 02²4'08.71671"S; 48 $14^{\prime} 50.42774^{\prime \prime}$; DU2 $02^{\circ} 20^{\prime} 59.68037^{\prime \prime} \mathrm{S} ; \quad 48^{\circ} 15^{\prime} 36.06262^{\prime \prime} \mathrm{W} ; \quad$ DU3 $\left.02^{\circ} 38^{\prime} 54.88752^{\prime \prime} \mathrm{S} ; 48^{\circ} 20^{\prime} 46,30510^{\prime \prime} \mathrm{W}\right)$. Each DU had 6 ha divided in three blocks of 2 ha each, which were subjected to different treatments $(\mathrm{T})$. Before the experiment, these areas consisted of secondary forest left fallow for approximately 15 years, originated after an orchard (in DU1), a short-cycle crop (in DU2) and of an abandoned degraded pasture of Brachiaria humidicola (Rendle) Schweick. (in DU3).

In DU1 and DU2, the secondary forest was cut and crushed manually and the African oil palm (Elaeis guineensis Jacq.) was planted with legumes and trees (T1), or was cut and crushed with a forest grinder (Tritucap) and the African oil palm was planted with legumes and trees (T2) or only legumes (T3). In DU3, the soil was ploughed and the African oil palm was planted with only legumes (T4) or manioc (Manihot esculenta Crantz) was added (T5) or trees were added (T6). Secondary forest (SF) remnants and adjacent to each DU were considered as the control treatment. The species were planted in all three treatments in March 2008 and February 2009, including legumes, palms and trees (Table 1). Oil palms were 18 months old when planted, at a density of $99 \mathrm{ha}^{-1}$.

In all of the demonstration units, the soil was prepared between December 2007 and January 2008; lime and fertiliser (Arad phosphate) were added to the pits 
Table 1 Species planted in six treatments (T) of agroforestry systems with African oil palm in the municipality of Tomé-Açu, eastern Amazon, Brazil

\begin{tabular}{|c|c|c|c|c|c|c|c|c|c|c|}
\hline \multirow[t]{5}{*}{ Species } & \multirow{5}{*}{ Family } & \multirow[t]{5}{*}{$\begin{array}{l}\text { Propagation } \\
\text { method }\end{array}$} & \multirow[t]{5}{*}{$\begin{array}{l}\text { Propagules } \\
\mathrm{ha}^{-1}\end{array}$} & \multirow{5}{*}{$\begin{array}{l}\text { Spacing (m) } \\
\text { Demonstration } \\
\text { Units }\end{array}$} & T1 & $\mathrm{T} 2$ & T3 & \multirow{3}{*}{\multicolumn{3}{|c|}{$\begin{array}{l}\text { T4 T5 T } \\
\text { DU3 } \\
\begin{array}{l}\text { Degraded } \\
\text { Pasture }\end{array}\end{array}$}} \\
\hline & & & & & \multicolumn{3}{|c|}{ DU1 and DU2 } & & & \\
\hline & & & & & Secondar & for & & & & \\
\hline & & & & & \multicolumn{3}{|c|}{$\begin{array}{l}\text { Cut and crushed } \\
\text { vegetation }\end{array}$} & \multirow{2}{*}{\multicolumn{3}{|c|}{$\begin{array}{l}\text { Soil was } \\
\text { ploughed }\end{array}$}} \\
\hline & & & & & Manually & & $\begin{array}{l}\text { Forest } \\
\text { grinder }\end{array}$ & & & \\
\hline $\begin{array}{l}\text { Cajanus cajan } \\
\text { (L.) Millsp. }\end{array}$ & Fabaceae & Seed & $50 \mathrm{~kg}$ & $0.25 \times 1.50$ & $x$ & $\times$ & $x$ & $\times$ & $x$ & $\times$ \\
\hline $\begin{array}{l}\text { Calophyllum } \\
\text { brasiliensis Cambess. }\end{array}$ & Clusiaceae & Seedling & 30 & $13.0 \times 22.5$ & $x$ & & $x$ & & & \\
\hline $\begin{array}{l}\text { Canavalia } \\
\text { ensiformis (L.) DC. }\end{array}$ & Fabaceae & Seedling & $80 \mathrm{~kg}$ & $0.30 \times 0.30$ & $x$ & $\times$ & $x$ & $\times$ & $x$ & $x$ \\
\hline Crotalaria juncea L. & Fabaceae & Seed & $5 \mathrm{~kg}$ & $0.25 \times 0.25$ & $x$ & $\times$ & $x$ & $x$ & $x$ & $x$ \\
\hline Euterpe oleracea Mart. & Arecaceae & Seedling & 125 & $6.0 \times 6.0$ & $x$ & & $x$ & & & \\
\hline $\begin{array}{l}\text { Gliricidia } \\
\text { sepium (Jacq.) Walp. }\end{array}$ & Fabaceae & Cutting & 280 & $3.0 \times 12.0$ & $x$ & & $x$ & & & $x$ \\
\hline $\begin{array}{l}\text { Gliricidia } \\
\text { sepium (Jacq.) Walp. }\end{array}$ & Fabaceae & Cutting & 540 & $\begin{array}{l}2.0 \text { (between } \\
\text { cuttings) }\end{array}$ & & $\times$ & & $x$ & $\times$ & \\
\hline Inga edulis Mart. & Fabaceae & Seedling & 515 & $3.0 \times 3.5 \times 6.0$ & $x$ & & $\times$ & & & $x$ \\
\hline Inga edulis Mart. & Fabaceae & Seedling & 540 & $3 \times 5 \times 17.5$ & & $x$ & & $x$ & $x$ & \\
\hline $\begin{array}{l}\text { Manihot } \\
\text { esculenta Crantz }\end{array}$ & Euphorbiaceae & Cutting & 600 & $1.0 \times 1.0 \times 3.0$ & $x$ & & $x$ & & $x$ & \\
\hline Mucuna sp. & Fabaceae & Seed & $20 \mathrm{~kg}$ & $0.50 \times 1.0$ & $x$ & $\times$ & $\times$ & & & \\
\hline Musa sp & Musaceae & Rhizome & 595 & $3.0 \times 3.0$ & $x$ & & $\times$ & & & $\times$ \\
\hline $\begin{array}{l}\text { Oenocarpus } \\
\text { bacaba Mart. }\end{array}$ & Arecaceae & Seedling & 85 & $4.5 \times 22.5$ & $x$ & & $x$ & & & $x$ \\
\hline $\begin{array}{l}\text { Sclerolobium } \\
\text { paniculatum Vogel }\end{array}$ & Fabaceae & Seedling & 28 & $14.0 \times 22.5$ & $x$ & & $x$ & & & \\
\hline Tabebuia sp. & Bignoniaceae & Seedling & 28 & $14.0 \times 22.5$ & $x$ & & $x$ & & & \\
\hline Theobroma cacao L. & Malvaceae & Seedling & 300 & $3.0 \times 3.5$ & $x$ & & $\times$ & & & $x$ \\
\hline $\begin{array}{l}\text { Tithonia diversifolia } \\
\text { (Hemsl.) A.Gray }\end{array}$ & Asteraceae & Cutting & 331 & $\begin{array}{l}2.0 \text { (between } \\
\text { cuttings) }\end{array}$ & $x$ & $x$ & $x$ & $x$ & $x$ & $x$ \\
\hline Cedrela odorata L. & Meliaceae & Seedling & 15 & $27 \times 22,5$ & & & & & & $x$ \\
\hline
\end{tabular}

of the oil palms in January 2008. Organic fertilisers (with Canavalia ensiformis (L.) DC. and Euterpe oleracea seeds) were added twice a year, around the oil palms. Weeding between the rows was manually done two to three times a year and selective weeding in oil palms crowns was done when necessary. Herbicide was applied in 2009 to one half of each treatment area at DU3; nevertheless, the samples of DU3 were analysed as one group because the seedbank was collected before the use of herbicide. The influence of the herbicide in the above-ground composition can be found in Lacerda et al. (2013).

\section{Soil seedbank}

The soil seedbank was studied using the emergence method. In each treatment ( $a r e a=2$ ha) and secondary forest, 35 soil samples were randomly collected with a quadrat of $25 \times 25 \mathrm{~cm}\left(0.0625 \mathrm{~m}^{2}\right)$, from 0 to $5 \mathrm{~cm}$ soil depth. The soils samples were collected at the end of the dry season, in November 2008, 11 months after the preparation of the areas and the first planting of trees. The 420 soil samples were placed in labelled plastic bags and transported to the glasshouse of the Rural Federal University of the Amazon, in the city of Belém. Each sample was spread in a plastic tray $(30 \times 40 \mathrm{~cm})$ containing a fine layer $(5 \mathrm{~cm})$ of sterile substrate (vermiculite), and the trays were randomly distributed among the benches. To avoid contamination by seeds from outside the glasshouse, 50 control trays containing only vermiculite were distributed among the soil samples. No seedlings emerged in these control trays and therefore it was assumed that there was no seed contamination of the soil samples. 
The trays were monitored and irrigated daily for one hour. Emerged seedlings were identified, recorded and removed when they were 30 days old. All the germinated individuals were identified and counted in monthly floristic surveys. After the fourth, sixth and eighth months, the soil with no new recruitment was turned upside down to expose covered seeds to light. The samples were monitored for ten months until no germination could be observed.

\section{Above-ground communities}

In all the treatments, the floristic composition of the above-ground community was recorded with annual floristic surveys conducted in the month of July from 2008 to 2011. In 2008, the first floristic survey was collected four months before the soil seedbank sampling. Twelve plots of $2 \times 2 \mathrm{~m}$ were randomly allocated in all the treatments. Within these plots, all individuals with height $<1.5 \mathrm{~m}$ were inventoried. Species identification was conducted in loco with the assistance of a parataxonomist and/or by comparison to specimens at the Herbarium of the Museu Emílio Goeldi Museum in Belém.

\section{Statistical analysis}

The effect of the treatments on the density and diversity of the soil seedbank was evaluated with the Mann-Whitney $U$-test, used for nonparametric data. The percentage of the abundance of woody species (trees, shrubs, lianas) present in the DU was used as a measure of the forest regeneration potential (PFR), and the percentage of herbaceous species present in the secondary forest was used as a measure of the invasion potential (PI). The diversity was analysed based on the richness (S), Shannon $(\mathrm{H})$ and evenness indices (J). The floristic similarity between the soil seedbank (of November 2008) and the above-ground composition, in July of the 2008, 2009, 2010 and 2011, was analysed with the Jaccard similarity coefficient (Brower et al., 1998).

\section{Results}

\section{Seedbank composition}

A total of 129 species germinated from the soil seedbank, belonging to 84 genera and 43 families. Diversity and seed density were not significantly different between treatments of the same DU; so the DU were compared. Seed densities in DU1 (mean of 5738 seeds $\mathrm{m}^{-2}$ ) were much higher than DU2, DU3 and the secondary forest (mean of 1012, 1195 and
1048 seeds $\mathrm{m}^{-2}$ respectively). Diversity indices were lowest in DU3 (S: 45 species, $\mathrm{H}^{\prime}=1.60, \mathrm{~J}=0.42$ ) (Table 2).

A large proportion of species $(47 \%)$ occurred in all three DU, and $38 \%$ were present in more than $50 \%$ of the plots; 24 species (19\%) were exclusive to the secondary forests, 74 species $(76 \%)$ occurred in both environments, and 31 species (24\%) occurred only in the DU. Jaccard similarity of seedbank among the treatments within a given DU was high $(58 \%, 59 \%$ and $51 \%$ in DU1, DU2 and DU3 respectively); among the different DU treatments, there was also relatively high similarity (mean of 50\%); The similarity among seedbank of the secondary forest treatments was $57 \%$. The forest regeneration potential of woody plants (trees, shrubs and lianas) were $47 \%, 41 \%, 2 \%$ in DU1, DU2 and DU3 respectively; the invasion potential of herbs in secondary forests was $78 \%$.

Most species were found in relatively low numbers in the seedbank. Of the 129 species, only 25 represented approximately $90 \%$ of the total of germinated seeds, considering all the DU and secondary forest areas studied (Table 3). These species with higher density also occurred more frequently. Miconia ceramicarpa (DC.) Cogn. exhibited high densities in all treatments, except those of DU3. The most abundant trees, shrubs and lianas had higher seed densities in the secondary forests than in the treatments (Table 3). Examples include $M$. ceramicarpa (in the three DU), Mikania congesta DC., Piper aduncum L., Sabicea aspera Aubl., Solanum jurubeba Rich. and Trema micrantha (L.) Blume (especially in DU2). Among the herbs, two groups were differentiated: (i) species with similar densities in both the DU and the secondary forest (such as Borreria verticillata G. Mey., Coutoubea spicata Aubl., Hyptis atrorubens Point., Oldenlandia lancifolia DC., Phyllanthus niruri L. and Scleria pterota Presl.) and (ii) species with higher densities in the DU (such as Borreria latifolia K. Schum., Cyperus diffusus Vahl, Dichromena ciliata Vahl, Eupatorium odoratum L., Fimbristylis miliacea (L.) Vahl, Lindernia crustacea (L.) F. Muell., Ludwigia hyssopifolia (G. Don) Exell and Panicum pilosum Sw.).

\section{Seedbank and above-ground communities}

From above-ground community surveys, there were a total of 144, 197 and 127 species in DU1, DU2 and DU3 respectively. Species richness in DU3 was the lowest in all analysed years (Table 4). Diversity and density were not different between treatments of the same DU. Many species from above-ground communities $(40 \%, 48 \%$ and $54 \%$ of the species at DU1, DU2 and DU3, respectively) occurred in only one 
Table 2 Density of seed (seeds $\mathrm{m}^{-2}$ ), richness (S), Shannon diversity $\left(\mathrm{H}^{\prime}\right)$ and evenness $(\mathrm{J})$ of the seedbanks in the three demonstration units (DU) of agroforestry systems with African oil palm in the municipality of Tomé-Açu, eastern Amazon, Brazil. In columns, values followed by the same letter are statistically different $(P<0.05 \%)$; letters represent ranking by the Fisher's LSD post hoc test

\begin{tabular}{|c|c|c|c|c|c|}
\hline Demonstration units & Treatments & Seeds $\mathrm{m}^{-2}$ & $\mathrm{~S}$ & $\mathrm{H}^{\prime}$ & $\mathrm{J}$ \\
\hline \multirow[t]{3}{*}{ DU1 } & T1 & 5707.9 & 69 & 2.55 & 0.60 \\
\hline & $\mathrm{T} 2$ & 5370.5 & 59 & 1.85 & 0.45 \\
\hline & T3 & 6137.6 & 63 & 1.94 & 0.47 \\
\hline Mean & & $5738.67 a$ & $64 a$ & $2.11 \mathrm{a}$ & $0.51 a$ \\
\hline \multirow[t]{3}{*}{ DU2 } & $\mathrm{T} 1$ & 868.1 & 54 & 2.75 & 0.69 \\
\hline & $\mathrm{T} 2$ & 732.8 & 61 & 2.93 & 0.71 \\
\hline & T3 & 1457.8 & 57 & 3.03 & 0.75 \\
\hline Mean & & $1019.57 b$ & $57 a$ & $2.90 \mathrm{a}$ & $0.72 a$ \\
\hline \multirow[t]{3}{*}{ DU3 } & $\mathrm{T} 4$ & 1742.2 & 40 & 1.63 & 0.44 \\
\hline & T5 & 597.0 & 45 & 1.68 & 0.44 \\
\hline & T6 & 1245.2 & 51 & 1.50 & 0.38 \\
\hline Mean & & $1194.80 \mathrm{~b}$ & $45 b$ & $1.60 \mathrm{~b}$ & $0.42 b$ \\
\hline \multirow[t]{3}{*}{ Secondary forests } & SF1 & 1222.4 & 72 & 2.22 & 0.52 \\
\hline & SF2 & 1150.2 & 67 & 2.91 & 0.69 \\
\hline & SF3 & 769.8 & 62 & 3.04 & 0.74 \\
\hline Mean & & $1047.47 b$ & $67 a$ & $2.72 a$ & $0.65 a$ \\
\hline
\end{tabular}

Table 3 Relative density (\%) of the main species found in seedbank of the different demonstration units (DU) in agroforestry systems in the municipality of Tomé-Açu, eastern Amazon, Brazil. $\mathrm{U}=$ Mann-Whitney $U$-test value; $P=$ probability. Numbers in bold highlight area with highest density

\begin{tabular}{|c|c|c|c|c|c|c|c|c|c|}
\hline \multirow[b]{2}{*}{ Species } & \multirow[b]{2}{*}{ Life form } & \multicolumn{3}{|c|}{ Agroforestry systems } & \multicolumn{5}{|c|}{ Secondary forests } \\
\hline & & DU1 & DU2 & DU3 & SF1 & SF2 & SF3 & $U$ & $P$ \\
\hline Banara guianensis Aubl. & Tree & 0.1 & 2.1 & 0.2 & 1.4 & 2.7 & 10.2 & 8.2 & 0.042 \\
\hline Borreria latifolia K. Schum. & Herb & 0.7 & 5.6 & 0.2 & 0.04 & 0.6 & 1.2 & 8.5 & 0.036 \\
\hline Borreria verticillata G. Mey. & Herb & 2.0 & 7.2 & 3.4 & 1.9 & 1.2 & 1.3 & 4.2 & 0.240 \\
\hline Cecropia obtusa Trécul & Tree & 0.1 & 1.9 & 0.3 & 2.4 & 5.6 & 3.7 & 10.4 & 0.016 \\
\hline Coutoubea spicata Aubl & Herb & 0.4 & 1.9 & 0.6 & 2.2 & 1.3 & 0.9 & 3.8 & 0.289 \\
\hline Cyperus diffusus Vahl & Herb & 6.0 & 0.6 & 2.8 & 0.4 & 0.1 & 0.5 & 9.2 & 0.017 \\
\hline Dichromena ciliata Vahl & Herb & 3.7 & 3.0 & 3.5 & 0.3 & 0.1 & 1.8 & 8.4 & 0.038 \\
\hline Eupatorium odoratum L. & Herb & - & 1.6 & 0.1 & 2.2 & 3.3 & 0.4 & 9.1 & 0.028 \\
\hline Fimbristylis miliacea (L.) Vahl & Herb & 10.0 & 8.1 & 41.3 & 0.3 & 1.0 & 1.5 & 8.6 & 0.034 \\
\hline Gouania cornifolia Reissek & Liana & - & 0.6 & 0.04 & 1.8 & 2.3 & 8.1 & 10.2 & 0.017 \\
\hline Hyptis atrorubens Poit. & Herb & 1.4 & 0.3 & 0.02 & - & 0.2 & - & 7.7 & 0.052 \\
\hline Lindernia crustacea (L.) F. Muell. & Herb & 7.8 & 1.8 & 38.0 & 0.8 & 0.8 & 0.6 & 8.4 & 0.039 \\
\hline Ludwigia hyssopifolia (G. Don) Exell & Herb & 9.5 & 0.1 & 2.2 & 0.1 & 0.1 & 0.2 & 9.6 & 0.022 \\
\hline Miconia ceramicarpa (DC.) Cogn. & Shrub & 43.7 & 15.6 & 0.4 & 54.6 & 23.7 & 11.0 & 9.5 & 0.024 \\
\hline Mikania congesta DC. & Liana & 1.5 & 3.2 & 0.1 & 1.2 & 6.4 & 1.3 & 8.2 & 0.042 \\
\hline Oldenlandia lancifolia DC. & Herb & 1.1 & 0.1 & 1.1 & 3.0 & 0.1 & 0.1 & 5.1 & 0.163 \\
\hline Panicum pilosum Sw. & Herb & 0.9 & 2.2 & 0.3 & 0.1 & 1.0 & 3.1 & 7 & 0.070 \\
\hline Phyllanthus niruri L. & Herb & 0.2 & 4.8 & 0.6 & 0.5 & 0.3 & 1.5 & 4.6 & 0.202 \\
\hline Piper aduncum L. & Shrub & 0.1 & 9.2 & 0.1 & 5.5 & 9.2 & 1.6 & 9.5 & 0.023 \\
\hline Pourouma guianensis Aubl. & Tree & - & 0.1 & 0.04 & 1.0 & 2.5 & 4.8 & 9 & 0.029 \\
\hline Sabicea aspera Aubl. & Liana & 0.3 & 4.7 & 0.2 & 3.3 & 4.4 & 5.0 & 9.4 & 0.025 \\
\hline Scleria pterota Presl. & Herb & 1.7 & 4.3 & 0.1 & 1.6 & 2.9 & 3.7 & 6.3 & 0.098 \\
\hline Solanum juripeba Rich & Shrub & 0.2 & 1.8 & 0.2 & 2.7 & 3.3 & 1.7 & 9.6 & 0.022 \\
\hline Trema micrantha (L.) Blume & Tree & 0.1 & 7.4 & 0.5 & 2.8 & 9.5 & 6.4 & 8.8 & 0.032 \\
\hline Vismia guianensis (Aubl.) Choysi & Tree & 0.1 & 0.9 & 0.1 & 1.3 & 7.9 & 18.8 & 9.6 & 0.022 \\
\hline Total & - & 91.4 & 89.0 & 96.3 & 91.4 & 90.4 & 89.3 & - & - \\
\hline
\end{tabular}

year between 2008 and 2011. Many species from seedbank did not occur in the following years $(46 \%, 47 \%$ e $51 \%$ of the species in DU1, DU2 and DU3 respectively).
Only 34 species from the seedbank occurred in all three following years $(2009,2010$ and 2011) in at least one DU (Table 5); five of these species occurred at the three DU (Borreria latifolia K.Schum., Borreria 
Table 4 Number of inventoried species at the demonstration units (DU) and secondary forests (SF) in agroforestry systems in the municipality of Tomé-Açu, eastern Amazon, Brazil. Number of species similar to the seedbanks are in parentheses

\begin{tabular}{llllll}
\hline & $\begin{array}{l}\text { Seedbank } \\
\text { Demonstration units }\end{array}$ & \multicolumn{2}{l}{ Above-ground communities } & \\
\cline { 3 - 5 } & November 2008 & July 2008 & July 2009 & July 2010 & July 2011 \\
\hline DU1 & 83 & $91(59)$ & $76(30)$ & $69(31)$ & $81(39)$ \\
DU2 & 76 & $96(51)$ & $107(24)$ & $92(26)$ & $84(34)$ \\
DU3 & 65 & $44(36)$ & $50(20)$ & $67(23)$ & $70(27)$ \\
SF1 & 72 & $63(31)$ & $61(5)$ & $47(6)$ & $75(11)$ \\
SF2 & 67 & $60(28)$ & $70(09)$ & $52(03)$ & $38(02)$ \\
SF3 & 62 & $53(28$ & $(53(04)$ & $43(06)$ \\
\hline
\end{tabular}

Table 5 Presence (1) and absence (0) of the seedbank species (SB) with high temporal frequency at the above-ground communities in agroforestry systems in the municipality of Tomé-Açu, eastern Amazon, Brazil. Soil seedbank sampling was collected in November 2008 and above-ground communities surveyed in July of 2008, 2009, 2010 and 2011

\begin{tabular}{|c|c|c|c|c|c|c|c|c|c|c|c|c|c|c|c|c|}
\hline \multirow[b]{3}{*}{ Species } & \multirow[b]{3}{*}{ Life form } & \multicolumn{5}{|c|}{ DU1 } & \multicolumn{5}{|c|}{ DU2 } & \multicolumn{5}{|c|}{ DU3 } \\
\hline & & \multirow{2}{*}{$\begin{array}{l}\text { SB } \\
08\end{array}$} & \multicolumn{4}{|c|}{$\begin{array}{l}\text { Above-ground } \\
\text { Communities }\end{array}$} & \multirow{2}{*}{$\begin{array}{l}\text { SB } \\
08\end{array}$} & \multicolumn{4}{|c|}{$\begin{array}{l}\text { Above-ground } \\
\text { Communities }\end{array}$} & \multirow{2}{*}{$\begin{array}{l}\text { SB } \\
08\end{array}$} & \multicolumn{4}{|c|}{$\begin{array}{l}\text { Above-ground } \\
\text { Communities }\end{array}$} \\
\hline & & & 08 & 09 & 10 & 11 & & 08 & 09 & 10 & 11 & & 08 & 09 & 10 & 11 \\
\hline Alternanthera ficoidea R.Br. & Herb & 1 & 1 & 1 & 1 & 1 & 0 & 0 & 0 & 0 & 0 & 0 & 0 & 1 & 0 & 0 \\
\hline Banara guianensis Aubl. & Tree & 1 & 1 & 1 & 0 & 1 & 1 & 1 & 1 & 1 & 1 & 1 & 0 & 0 & 1 & 1 \\
\hline Borreria latifolia K.Schum. & Herb & 1 & 1 & 1 & 1 & 1 & 1 & 1 & 1 & 1 & 1 & 1 & 1 & 1 & 1 & 1 \\
\hline Borreria verticillata G.Mey. & Herb & 1 & 1 & 1 & 1 & 1 & 1 & 1 & 1 & 1 & 1 & 1 & 1 & 1 & 1 & 1 \\
\hline Brachiaria humidicola (Rendle) Schweick. & Herb & 0 & 0 & 0 & 0 & 0 & 0 & 0 & 0 & 0 & 0 & 1 & 1 & 1 & 1 & 1 \\
\hline Calopogonium mucunoides Desv. & Herb & 1 & 1 & 1 & 1 & 1 & 1 & 1 & 1 & 1 & 1 & 1 & 1 & 1 & 1 & 1 \\
\hline Casearia arborea Urb. & Tree & 1 & 0 & 0 & 0 & 0 & 1 & 0 & 1 & 1 & 1 & 0 & 0 & 0 & 0 & 0 \\
\hline Commelina longicaulis Jacq. & Herb & 1 & 1 & 1 & 1 & 1 & 0 & 0 & 0 & 0 & 0 & 0 & 0 & 0 & 0 & 1 \\
\hline Cordia multispicata Cham. & Shrub & 1 & 1 & 1 & 1 & 1 & 1 & 1 & 1 & 1 & 1 & 0 & 0 & 0 & 1 & 1 \\
\hline Croton lobatus L. & Herb & 1 & 1 & 1 & 1 & 1 & 0 & 0 & 1 & 1 & 1 & 0 & 0 & 0 & 1 & 1 \\
\hline Croton trinitatis Millsp. & Herb & 1 & 0 & 1 & 1 & 1 & 0 & 0 & 1 & 1 & 0 & 1 & 0 & 1 & 1 & 0 \\
\hline Desmodium barbatum Benth. \& Oerst. & Herb & 1 & 1 & 1 & 1 & 1 & 0 & 0 & 1 & 1 & 1 & 1 & 0 & 1 & 0 & 1 \\
\hline Elephantopus mollis Kunth & Herb & 0 & 0 & 1 & 0 & 1 & 1 & 0 & 1 & 1 & 1 & 0 & 0 & 1 & 0 & 1 \\
\hline Emilia sonchifolia (L.) DC. & Herb & 1 & 1 & 1 & 1 & 1 & 1 & 1 & 1 & 0 & 1 & 1 & 0 & 1 & 1 & 1 \\
\hline Fimbristylis miliacea (L.) Vahl & Herb & 1 & 1 & 1 & 1 & 1 & 1 & 0 & 0 & 1 & 1 & 1 & 1 & 1 & 1 & 1 \\
\hline Hyptis atrorubens Poit. & Herb & 1 & 1 & 1 & 1 & 1 & 1 & 0 & 0 & 0 & 1 & 1 & 0 & 0 & 0 & 1 \\
\hline $\begin{array}{l}\text { Ipomoea bahiensis Willd. } \\
\text { ex Roem. \& Schult. }\end{array}$ & Liana & 1 & 1 & 1 & 1 & 1 & 0 & 0 & 1 & 0 & 0 & 0 & 0 & 1 & 0 & 0 \\
\hline Jacaranda copaia D.Don & Tree & 0 & 0 & 0 & 0 & 0 & 1 & 0 & 1 & 1 & 1 & 0 & 0 & 0 & 0 & 0 \\
\hline Lindernia crustacea (L.) F. Muell. & Herb & 1 & 0 & 0 & 0 & 1 & 1 & 0 & 0 & 1 & 1 & 1 & 0 & 1 & 1 & 1 \\
\hline Ludwigia hyssopifolia (G. Don) Excell. & Herb & 1 & 1 & 1 & 1 & 1 & 1 & 1 & 1 & 0 & 0 & 1 & 1 & 1 & 1 & 1 \\
\hline Mandevilla hirsuta (Rich.) K.Schum. & Liana & 1 & 0 & 0 & 1 & 1 & 1 & 1 & 1 & 1 & 1 & 0 & 0 & 0 & 1 & 0 \\
\hline Mimosa pudica L. & Shrub & 1 & 0 & 1 & 1 & 1 & 0 & 0 & 1 & 1 & 0 & 1 & 0 & 1 & 1 & 1 \\
\hline Panicum pilosum Sw. & Herb & 1 & 1 & 1 & 1 & 1 & 1 & 1 & 1 & 1 & 1 & 1 & 0 & 0 & 1 & 1 \\
\hline Phyllanthus niruri L. & Herb & 1 & 1 & 1 & 1 & 1 & 1 & 1 & 1 & 1 & 1 & 1 & 1 & 1 & 1 & 1 \\
\hline Rolandra argentea Rottb. & Shrub & 1 & 1 & 1 & 1 & 1 & 1 & 1 & 1 & 1 & 1 & 1 & 1 & 1 & 1 & 1 \\
\hline Scleria pterota Presl. & Herb & 1 & 0 & 0 & 1 & 1 & 1 & 0 & 0 & 1 & 1 & 1 & 1 & 1 & 1 & 1 \\
\hline Scoparia dulcis L. & Herb & 1 & 1 & 1 & 1 & 1 & 1 & 0 & 0 & 0 & 0 & 1 & 0 & 0 & 1 & 1 \\
\hline Sebastiania corniculata Müll.Arg. & Herb & 1 & 1 & 0 & 0 & 1 & 1 & 1 & 1 & 1 & 1 & 1 & 1 & 0 & 1 & 1 \\
\hline Solanum crinitum Lam. & Shrub & 0 & 0 & 1 & 0 & 1 & 1 & 0 & 1 & 1 & 1 & 1 & 0 & 1 & 1 & 0 \\
\hline Spigelia anthelmia L. & Herb & 1 & 1 & 1 & 1 & 1 & 1 & 1 & 1 & 0 & 1 & 0 & 0 & 1 & 0 & 1 \\
\hline Trema micrantha (L.) Blume & Tree & 1 & 0 & 0 & 0 & 0 & 1 & 0 & 0 & 1 & 1 & 1 & 1 & 1 & 1 & 1 \\
\hline Vismia guianensis (Aubl.) Choysi & Tree & 1 & 1 & 1 & 1 & 1 & 1 & 1 & 1 & 1 & 1 & 1 & 0 & 1 & 0 & 1 \\
\hline Wulffia baccata (L.) Kuntze & Tree & 1 & 1 & 1 & 1 & 1 & 1 & 1 & 1 & 1 & 1 & 1 & 0 & 1 & 1 & 1 \\
\hline Zanthoxylum rhoifolium Lam. & Tree & 1 & 0 & 1 & 1 & 1 & 1 & 1 & 1 & 1 & 1 & 0 & 0 & 0 & 0 & 0 \\
\hline
\end{tabular}

verticillata G.Mey., Calopogonium mucunoides Desv. (planted leguminous), Phyllanthus niruri L. and Rolandra argentea Rottb.).
Jaccard similarity between the seedbank (in November 2008) and the above-ground composition surveyed in July 2008 was high $(51 \%, 42 \%$ and $39 \%$ in DU1, 
DU2 and DU3 respectively). The similarity between these seedbanks and the above-ground composition decreased by more than $50 \%$ in 2009 and increased progressively until 2011. This pattern was found in all DU (Fig. 1A). In the secondary forests, this pattern did not occur. The similarity between the seedbank in the secondary forests and above-ground composition was always very low (Fig. 1B).

\section{Discussion}

In the present study, it was expected to find differences among the treatments within a given DU. The initial hypothesis was that the time elapsed between the imposition of the treatments and the collection of soils for the study (11 months) had been too short for the treatments to affect the soil seedbank. However, the main species of the seedbank and the species that emerged after the initiation of the treatments have short life cycles, and many species had already reproduced before the soil collection. The seedbank of pioneer species is very dynamic because the repositioning of seeds lost by germination or mortality is continuous (Dalling et al., 1998). Therefore, contrary to the expected results, there were no significant differences among the treatments within a given DU, but rather between DU. Usually the density and diversity present in the seedbank of demonstration units are influenced by agricultural practices such as soil preparation, the

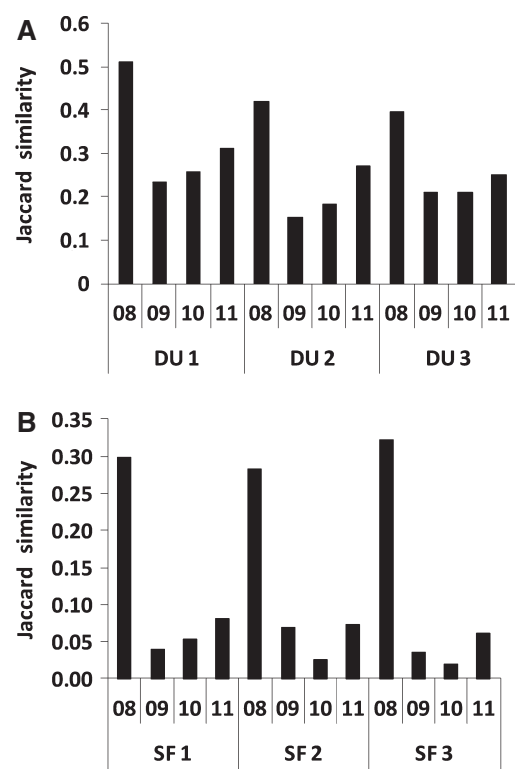

Fig. 1 Jaccard similarity between the species composition of the seedbank surveyed in November 2008 and the species composition of the above-ground communities surveyed in July of 2008, 2009, 2010 and 2011 in the demonstration units (DU) of the experimental areas (A) and in the secondary forests considered to be the control areas (B), in Tomé-Açu, Pará, Brazil. use of green manure (Mirsky et al., 2010) and weed management (Baumgartner et al., 2007). Because the treatments applied in each DU were not different, the use of the Tritucap equipment in the soil preparation was comparable to manual crushing, a fact that reaffirms the use of Tritucap equipment to preserve biodiversity; this chipper also had good results for species conservation in other areas in the north-east of the state of Pará, in comparison with another forest chipper (Rodrigues et al., 2007).

The differences in diversity among the DU indicate that the history of land use prior to the implementation of the experiment might have been more important than the treatments. The importance of land-use history has been emphasised in the literature (Bertoncini \& Rodrigues, 2008; Lindner, 2009). DU1 and DU2, which were previously fallow areas, exhibited highest diversity that was similar to the diversity found in the secondary forests. In DU3, which was previously an abandoned pasture, the diversity was much lower; this result might be related to the relatively high abundance of Brachiaria humidicola in this DU.

Brachiaria humidicola displays an aggressive growth and a high degree of adaptation to the Amazon region, resulting in its efficient soil cover and high capacity to compete with weeds (Dias-Filho, 1986). The dominance of this forage species might also have reduced the abundance of woody species in DU3 (98\% of the germinated seeds were herbs). Several studies have indicated the importance of forage weed composition as inhibitors of the successional process in abandoned pastures (Esquivel et al., 2008).

The highest density found in DU1 might have been caused by persistent seeds that previously occupied this area and that remained in the soil after the implantation of the present agroforestry systems. At DU1, there were perennial crops (orchard) for which the soil disturbances were far less intense than in DU2, where there was crop rotation. Seed accumulation is greater at the surface of soils with low management intensity (Sosnoskie et al., 2009). However, the predation and removal of seeds and the environmental variation could have also influenced the difference in density among the DU (Albrecht \& Auerswald, 2003; GarcíaOrth \& Martínez-Ramos, 2008).

Although woody species formed a greater proportion of the seeds in the secondary forests, the presence of those species was high in the treatments, especially in DU1 and DU2. This high proportion is an indicator of the potential of forest regeneration that still remains in these agroforestry systems. Miconia ceramicarpa, Piper aduncum, Sabicea aspera and Trema micrantha have a marked importance as facilitators of the regeneration process in these areas. Conversely, in the 
secondary forests, the potential for invasion was low (approximately $22 \%$ ), indicating a good conservation status of these successional forests. Several authors have stressed the importance of woody species in the beginning of forest regeneration (Costa et al., 2002; Vieira \& Proctor, 2007; López-Toledo \& MartínezRamos, 2011).

The potential of forest regeneration of $2 \%$ in DU3 confirms the degradation of biodiversity caused by Brachiaria humidicola. In degraded pastures, natural recovery is more difficult and certain restoration techniques can be used to accelerate the regeneration (Bertoncini \& Rodrigues, 2008). The treatments implanted in DU3 in 2008 showed good results for increasing species diversity from 2008 to 2011, as presented by Lacerda et al. (2013).

The high similarity in the floristic composition found within and among the DU indicated a low heterogeneity and floristic differentiation of the region studied. This pattern resulted from the high frequency of a large quantity of species, such as the 49 species that occurred in more than $50 \%$ of the plots, and from the strong dominance of a few species, such as the 25 species shown in Table 3, which represented approximately $90 \%$ of the total of germinated seeds. Miconia ceramicarpa, Fimbristylis miliacea, Lindernia crustacea, Ludwigia hyssopifolia and Piper aduncum were dominant in at least one treatment in each DU. This dominance of a few species also influenced the low evenness found in the treatments. The dominance of only one species is common in the persistent seedbank, as observed by Garwood (1989).

The higher floristic and structural similarity between the soil seedbank and the emerged flora in the first year (2008) and the reduction in such similarity in the subsequent years $(2009,2010$ and 2011) showed that the seedbank reflected the composition of the past more than the composition of the future. Considering that the emerged flora in 2008 had been surveyed (in July 2008) before seedbank soils sampling (performed in November 2008), the soil disturbances and the management applied in the systems (such as preparation of the area, arrangement of planted species and weeding) stimulated the germination of other species, most likely due to the environmental changes that occurred.

The seedbank may be considered a memory of the community of annual weeds, but not in the medium or long term (Thompson et al., 1997). The relationship between the seedbank and above-ground composition is subject to several different factors, such as spatial and physiological variation of the seeds, the percentage of species that are recruited and the management of the area (Davis et al., 2005, 2008).
The weak relationship between the seedbank and the emerged plants in the following years may be exemplified by the species Casearia arborea Urb. and Trema micrantha (L.) Blume (in DU1) and Scoparia dulcis L. (in DU2), which were present in the seedbank but absent at the above-ground flora, and conversely, by those absent at the seedbank but with high frequency at the above-ground flora, such as Croton lobatus L. and Croton trinitatis Millsp. (in DU2) and Mimosa pudica L. (in DU3). Besides presence and absence, the densities of some species increased or decreased over time, according to the seedbank, as shown in Lacerda (2012). Alterations in the agricultural environment decreased the influence of the seedbank on the emergence of plants and changed the floristic composition of the area (Davis et al., 2005).

The presence of vegetative propagules in the soil, such as stumps and roots remaining from the previous vegetation, might also have contributed to the floristic differences found between the seedbank and the emerged flora. Resprouting is an important regeneration mechanism for tree and shrub species (Vieira \& Proctor, 2007), in contrast to the species present in seedbanks, which are usually herbs.

\section{Conclusion}

The species present in the seedbank of agroforestry systems is highly influenced by the secondary forest. The land-use history was more important for explaining the diversity and density of the soil seedbank than the preparation and arrangement of crops species. The secondary forests, which were the former use of the DU and were present in adjacent areas, may have contributed to the dispersal of propagules that will favour forest regeneration in the agroforestry systems. Maintaining secondary forests within farms might increase the potential for regeneration on a regional scale.

The decreases in similarity between the floristic composition of the seedbank and the flora that emerged in the subsequent years indicate: (i) that the seedbank showed the past better than the future and (ii) that there was a temporal fluctuation of the emergent species composition, with a few common species returning over time. Temporal studies on the dynamics of weeds are necessary to assist in their management, especially on the properties of small producers that do not use chemical inputs to control weeds.

\section{Acknowledgements}

This project has benefited from the support of the Natura Inovação e Tecnologias de Produtos Ltda., of the Embrapa Amazônia Oriental, of the Universidade 
Federal Rural da Amazônia. The Conselho Nacional de Desenvolvimento Científico e Tecnológico (CNPq) provided a scholarship to Fernando da Costa Brito Lacerda. We thank Kênia Samara, Elayne Braga, Denison Lima, Magno Reis, Livia Lobato, Heraldo Silva for their help in the field and glasshouse and Mr. Antonio Carlos and Mr. Manuel Cordeiro for their efficiency and enthusiasm during plant identification.

\section{References}

Aковundu IO, Ekeleme F \& Chiкоye D (1999) Influence of fallow management systems and frequency of cropping on weed growth and crop yield. Weed Research 39, 241-256.

Albrecht H \& Auerswald K (2003) Arable weed seedbanks and their relation to soil properties. Aspects of Applied Biology 69, 11-20.

Baumgartner K, Steenwerth K.L. \& Veilleux L (2007) Effects of organic and conventional practices on weed control in a perennial cropping system. Weed Science $\mathbf{5 5}$, 352-358.

Benech-Arnold RL, Sanchez RA, Forcella F, Kruck BC \& Ghersa CM (2000) Environmental control of dormancy in weed seed banks in soil. Field crops research 67, 105-122.

Bertoncini AP \& Rodrigues R (2008) Forest restoration in an indigenous land considering a forest remnant influence (Avaí, São Paulo State, Brazil). Forest Ecology and Management 255, 513-521.

Brower EJ, Zar JH \& VAN Enden CN (1998) Field and laboratory methods for general ecology, $4^{\circ} \mathrm{ed}$. WCB/ McGraw, New York.

Costa JR, Mitja D \& Leal Filho N (2002) Caracterização dos bancos de sementes de plantas invasoras em pastagens cultivadas na Amazônia Central. Embrapa Roraima, Boa Vista (Boletim de Pesquisa, 3), Brazil.

Dalling JW, Swaine MD \& Garwood NC (1998) Dispersal patterns and seedbank dynamics of pioneer trees in moist tropical forest. Ecology 79, 564-578.

Davis AS, Renner KA \& Gross KL (2005) Weed seedbank and community shifts in a long-term cropping systems experiment. Weed Science 53, 296-306.

Davis AS, Schutte BJ, Iannuzzi J \& Renner KA (2008) Chemical and Physical Defense of Weed Seeds in Relation to Soil Seedbank Persistence. Weed Science 56(5), 676-684.

Dias-Filho MB (1986) Espécies forrageiras e estabelecimento de pastagens na Amazônia. In: Pastagens na Amazônia, (eds AM Peixoto, JC Moura \& VP Faria), 27-54. FEALQ, Piracicaba, Brazil.

Esquivel MJ, Harvey CA, Finegan B, Casanoves F \& SKARPE C (2008) Effects of pasture management on the natural regeneration of neotropical trees. Journal of Applied Ecology 45, 371-380.

Forcella F, Wilson WG \& Dekker J (1996) Weed seedbank emergence across the corn belt. Weed Science $\mathbf{4 5}$, 67-76.

García-Orth X \& Martínez-Ramos M (2008) Seed dynamics of early and late successional tree species in tropical abandoned pastures: seed burial as a way of evading predation. Restoration Ecology 16, 435443.

Garwood NC (1989) Tropical soil seedbanks: a review. In: Ecology of soil seedbank (eds MA LECK, VT PARKER \& RL Simpson), 149-209. Academic Press, San Diego, CA.

Hume L \& Archibold OW (1986) The influence of a weedy habitat on the seed bank of na adjacent cultivated Field. Canadian Journal of Botany 64, 1879-1883.

Kass DCL \& Somarriba E (1999) Traditional fallows in Latin America. Agroforestry Systems 47, 13-36.

LACERDA F (2012) Dinâmica das plantas espontâneas em sistemas agroflorestais no município de Tomé-Açu, Estado do Pará. MSc thesis, Universidade Federal Rural da Amazônia, Belém, Brazil.

Lacerda F, Miranda I, Kato OR, Bispo CJC \& Do Vale I (2013) Weed dynamics during the change of a degraded pasture to agroforestry system. Agroforestry Systems 87, 909-916.

LindNer A (2009) A rapid assessment approach on soil seed banks of Atlantic forest sites with different disturbance history in Rio de Janeiro, Brazil. Ecological Engineering 35, 829-835.

López-Toledo L \& Martínez-Ramos M (2011) The soil seed bank in abandoned tropical pastures: source of regeneration or invasion? Revista Mexicana de Biodiversidade 82, 663-678.

Luschei EC (2003) Comparison of the effectiveness of seedbank sampling to seedling counts in reducing the uncertainty in estimates of weed population size. Aspects of Applied Biology 69, 137-142.

Miranda IS, Mitja D \& Silva TS (2009) Mutual influence of forests and pastures on the seedbanks in the Eastern Amazon. Weed Research 49, 499-505.

Mirsky SB, Gallandt ER, Mortensen DA, Curran WS \& Shumway DL (2010) Reducing the germinable weed seedbank with soil disturbance and cover crops. Weed Research 50, 341-352.

Mitja D. \& Miranda IS (2010) Weed community dynamics in two pastures grown after clearing Brazilian Amazonian rainforest. Weed Research 50, 163-173.

Mitua D, Miranda IS, Velasquez E \& Lavelle P (2008) Plant species richness and floristic composition change along a rice-pasture sequence in subsistence farms of Brazilian Amazon, influence on the fallows biodiversity (Benfica, State of Pará). Agriculture, Ecosystems and Environment 124, 72-84.

Moran EF, Brondizio ES, Tucker JM, Silva-Forsberg MC, Mccracken S \& Falesi I (2000) Effects of soil fertility and land-use on forest succession in Amazonia. Forest Ecology and Management 139, 93-108.

Rodrigues MACM, Miranda IS \& Kato MSA (2007) Flora e estrutura da vegetação secundária após o uso de diferentes trituradores florestais. Pesquisa Agropecuaria Brasileira 42, 459-465.

Smith RG, Jabbour R, Hulting AG, Barbercheck ME \& Mortensen DA (2009) Effects of Initial Seed-Bank Density on Weed Seedling Emergence during the Transition to an Organic Feed-Grain Crop Rotation. Weed Science 57, 533-540. 
Sosnoskie LM, Herms CP, Cardina J \& Webster TM (2009) Seedbank and emerged weed communities fallowing adoption of glyphosate-resistant crops in a long-term tillage and rotation study. Weed Science 57, 261-270.

Steenwerth K, Baumgartner K, Belina K \& Veilleux L (2010) Vineyard Weed Seedbank Composition Responds to Glyphosate and Cultivation after Three Years. Weed Science 58, 310-316.
Thompson K, Bakker J \& Bekker R (1997) The Soil Seed Banks of North West Europe: Methodology, Density and Longevity. Cambridge University Press, Cambridge, UK.

Tuesca D, Puricelli E \& Papa EJC (2001) A long-term study of weed flora shifts in different tillage systems. Weed Research 41, 369-382.

Vieira ICG \& Proctor J (2007) Mechanisms of plant regeneration during succession after shifting cultivation in eastern Amazonia. Plant Ecology 192, 303-315. 